\title{
ESP TEACHING STRATEGIES OF UKRAINIAN BORDER GUARDS TRAINING ON THE EXPERINCE OF EUROPEAN UNION COUNTRIES
}

\author{
Oksana Komarnytska ${ }^{1}$, Andrii Balendr ${ }^{2}$, Ihor Bloschchynskyi ${ }^{3}$ \\ The National Academy of the State Border Guard Service of Ukraine \\ named after Bohdan Khmelnytskyi, Ukraine \\ E-Mail: ${ }^{1}$ o.i.komarnytska@gmail.com, ${ }^{2}$ drbalen@i.ua, ${ }^{3}$ i.bloshch@gmail.com
}

\begin{abstract}
The study identifies the ESP teaching strategies of the personnel of the State Border Guard Service of Ukraine (SBGSU) training in the framework of European language standards. According to the results of the needs analysis, the Ukrainian border guards require improving their professional foreign language competence based on the European educational standards and best practices. The main attention is paid to developing listening and speaking skills of border guards. The methodology of the course is aimed at forming the border guards' foreign-language professional competency, which will facilitate their effective service in the state border protection units. The course program provides border guards with the opportunity to develop the language competence and strategies they need to effectively engage in situations of professional communication that they can have at the border, both while conducting border surveillance activities and border checks.
\end{abstract}

Key words: English for Specific Purposes, border guards, European Union countries.

\section{INTRODUCTION}

This study took place in the context of a nationwide reform of the professional training of the personnel of the State Border Guard Service of Ukraine (SBGSU), in order to provide the Ukrainian border guards with the possibility to improve their professional foreign language competence according to the European educational standards and best practices.

The Ukrainian Border Guard Agency has been undergoing an intensive organizational and logistical reform in order to reach compliance with European Union (EU) Schengen standards and SBGSU development strategy by 2020. One of the Schengen requirements is that all Ukrainian border crossings be staffed with personnel fluent enough in English to handle international visitors, discuss cross-border incidents with international counterparts, and participate in international training and professional conferences. Although the Ukrainian National Border Guard Academy named after B. Khmelnytskyi (NADPSU) is contributing to this goal by providing cadets' courses in English, the border guards who are already working in the field require more English language training. Therefore, the decision was taken by the leadership of the SBGSU to organize professionally-oriented English Language courses for the border guard officers based on the experience of leading border guard institutions in the EU countries, in the framework

Submitted May $5^{\text {th }}, 2018$, accepted for publication October $30^{\text {th }}, 2018$ 
of the international cooperation project of the SBGSU and FRONTEX Agency (European Border and Coast Guard organization), taking into account the best practices of EU border guard agencies and creating the course under supervision of a native-speaking ESP course design specialist. The Intensive English Language Course (IELC) was developed by the specially designated working group and is presently conducted at the English Language department of NADPSU in Khmelnytskyi, Ukraine. So, the article envisages the experience of IELC development and implementing, created to ensure that the border guard officers develop the basic English language skills necessary to communicate in professional situations.

The course content was selected based on analyses of the professional requirements of the target population, their language wants and needs, and international language proficiency standards. The curriculum of the IELC was developed to provide NADPSU English instructors with a standardized basis for course development. It also provides benchmarks for both cadets and instructors to assist them in setting achievable goals and mapping student progress. The research of the theory and practice of border guard's foreign language training has been conducted by N. Ryndenko (2016), O. Babich (2017). Tendencies in education and training in the EU countries have been studied by S. Zaskaleta (2015), T. Krystopchuk (2014), N. Bidiuk (2010). The border guards' professional training research has been conducted by I. Bloshchynsky (2017), O. Didenko (2017). Harmonization of border guards' educational standards on the basis of European experience has been in the focus of attention of A. Balendr (2018). However, our studies have shown that there is no current research of the problem of Ukrainian border guards' foreign language training what regards European language standards. Therefore, the purpose of the article is to study the ESP teaching strategies of Ukrainian border guards' foreign language training in the framework of European language standards.

\section{METHODS}

The purpose of the research was achieved with the help of the needs analysis, in the framework of which there were conducted a number of consequent measures:

- defining and creating a list of stakeholders to be involved in the study;

- developing data collection instruments (questionnaires, interview questions, observation instruments, letters, etc.);

- collecting data through the following sources:

- questionnaires given to SBGS administration, program sponsors, international liaison officers and counterparts, officers from the previous intensive English course, and English language instructors (observations of acting border guard officers to see how English is actually used/needed on the job (task, situation, and language analysis);

- interviews with instructors of professional courses and border guard officers;

- $\quad$ site visits to training centers, border crossing points, and a temporary holding facility materials and professional document review (i.e. training documents, manuals and handbooks, Schengen codes);

- situation analysis;

- English language proficiency testing of students.

We analyzed available materials and documents from training centers, other similar language programs, and international counterparts (i.e. NADPSU, Federal Law- 
Enforcement Training Center, training institutions in Poland, Lithuania, Latvia, Estonia), Kyiv (Boryspil Airport, SBGS Administration), Border guard training center "Orshanets", Western Regional Directorate, Border Guard Division "Mostyska" (Temporary Holding Facility). After that the obtained data was analyzed and summarized, which resulted in compiling a Needs Analysis Report for the Administration of the SBGSU.

After the first pilot courses were accomplished, the developers group conducted full assessment to determine the adequacy of the curriculum and materials, the adequacy of teaching methods, the degree of satisfaction of listeners and teachers, the competence of teachers, as well as the effectiveness of materials and tests used at the courses. The following tools were used for this purpose:

- focus group for teachers: meeting with teachers in order to identify the strengths and weaknesses of existing methods and recommend changes;

- receiving feedback: development of anonymous detailed questionnaires to collect feedback from students on various aspects of courses, including books and materials, training, testing and evaluation, teaching aids and facilities and living conditions;

- test results: after completing the language proficiency tests, the percentage of students who reached the Language Proficiency levels planned for the certain category was determined;

- an expert assessment: involvement of an English language expert to conduct classroom observations, analyze the curriculum, as well as provide consultations with faculty and students in order to analyze the curriculum and formulate suggestions for improvement.

Based on the results of the evaluation, changes were made to the organization and implementation of the IELC.

\section{Results}

ESP teaching strategies of the personnel of the State Border Guard Service of Ukraine (SBGSU) training in the framework of European language standards considering the problem of the border guards' foreign language competence improvement is regarded on 3 levels:

Theoretical (needs analysis, language proficiency levels, goals, testing);

Practical (the roles and responsibility of the administration, students, teachers);

Methodological (teaching methodology; objectives of the IELC; learning methods).

\section{THEORETICAL LEVEL OF THE UKRAINIAN BORDER GUARDS’ FOREIGN LANGUAGE COMPETENCE DEVELOPMENT}

\subsection{Ukrainian Border Guards' foreign language competence needs analysis}

As for the theoretical level of the foreign language competence development, the results of the needs analysis were important to define the objectives for developing the curriculum, tests, materials and training activities for an intensive English course. Since any single source of information is likely to be incomplete, we have used triangulation in our approach (that is, obtaining information from two or more sources). Eighty three 
questionnaires were received. In addition, interviews with 26 people were conducted in the form of individual interviews and interviews in small focus groups.

Firstly, we conducted a needs assessment and analysis to determine:

- the situations in which Ukrainian border guards will use the English language;

- the objectives and purposes for which English is needed;

- the types of communication that will be used (e.g. written, spoken, formal, informal);

- the level of proficiency that will be required.

\subsection{Border Guards' English proficiency requirements}

The IELC Curriculum takes into account language proficiency levels as specified in the Interagency Language Roundtable (ILR) Proficiency Levels. An approximate mapping of ILR levels to other European proficiency level standards is shown in Table 1.

Table 1 English Language Proficiency Scales Comparison

\begin{tabular}{|c|c|c|c|c|}
\hline & Scale & Scale & Scale & Scale \\
\hline Entity & $\begin{array}{l}\text { ILR Interagency Language } \\
\text { Roundtable (US) }\end{array}$ & $\begin{array}{l}\text { NATO North } \\
\text { Atlantic Treaty } \\
\text { Organization }\end{array}$ & $\begin{array}{l}\text { Armed Forces } \\
\text { of Ukraine }\end{array}$ & $\begin{array}{l}\text { COE Council of } \\
\text { Europe }\end{array}$ \\
\hline Origin & \begin{tabular}{|l|} 
US Civil Service \\
Commission report 1956 \\
\end{tabular} & $\begin{array}{l}\text { Derived from the } \\
\text { ILR scale in } 1976 \\
\end{array}$ & $\begin{array}{l}\text { Inspired by } \\
\text { STANAG } 6001 \\
\end{array}$ & Inspired by ILR \\
\hline \multirow[t]{7}{*}{$\begin{array}{l}\text { Name of } \\
\text { Scale/ }\end{array}$} & $\begin{array}{l}\text { ILR Scale (including the } \\
\text { ILR OPI Oral Proficiency } \\
\text { Interview) }\end{array}$ & $\begin{array}{l}\text { STANAG 6001 } \\
\text { NATO } \\
\text { Standardization } \\
\text { Agreement } 6001\end{array}$ & \begin{tabular}{|l|} 
SLL \\
Standardized \\
Language \\
Levels
\end{tabular} & $\begin{array}{l}\text { CEF Common } \\
\text { European } \\
\text { Framework }\end{array}$ \\
\hline & \begin{tabular}{|l}
5 Educated Native \\
Proficiency
\end{tabular} & $\begin{array}{l}\text { Excellent } \mathbf{5} \\
\text { (Native) }\end{array}$ & & \\
\hline & $\begin{array}{l}\text { 4+ Advanced Professional } \\
\text { Proficiency, Plus } \\
\text { 4 Adv. Professional } \\
\text { Proficiency (tailored) } \\
\end{array}$ & $\begin{array}{l}4+\quad \text { Very Good } \\
4 \text { (Full } \\
\text { Professional) }\end{array}$ & & C2 Mastery \\
\hline & $\begin{array}{l}\text { 3+ General Professional } \\
\text { Proficiency, Plus } \\
\mathbf{3} \text { General Professional } \\
\text { Proficiency (abstract) }\end{array}$ & $\begin{array}{l}3+\text { Good } \\
3 \text { (Minimum } \\
\text { Professional) }\end{array}$ & \begin{tabular}{|l|}
3 \\
Professional
\end{tabular} & $\begin{array}{l}\text { Effective } \\
\text { C1 Operational } \\
\text { Proficiency }\end{array}$ \\
\hline & $\begin{array}{l}\text { 2+ Limited Working } \\
\text { Proficiency, Plus } \\
\text { 2 Limited Working } \\
\text { Proficiency (concrete) }\end{array}$ & $\begin{array}{l}2+ \\
2 \text { Fair (Limited } \\
\text { Working) }\end{array}$ & $\begin{array}{l}2+\text { Functional }+ \\
2 \text { functional }\end{array}$ & $\begin{array}{l}\text { B2+ Vantage plus } \\
\text { B2 Vantage }\end{array}$ \\
\hline & $\begin{array}{l}\text { 1+ Elementary Proficiency, } \\
\text { Plus } \\
\mathbf{1} \text { Elementary Proficiency } \\
\text { (survival) }\end{array}$ & 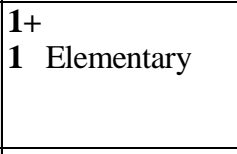 & $\begin{array}{ll}\text { 1+ } & \text { Survival+ } \\
1 & \text { Survival }\end{array}$ & $\begin{array}{l}\text { B1+ Threshold plus } \\
\text { B1 Threshold }\end{array}$ \\
\hline & $\begin{array}{l}\text { 0+ Memorized Proficiency } \\
\text { 0 No Proficiency }\end{array}$ & \begin{tabular}{|l|}
$\mathbf{0 +}$ \\
$\mathbf{0}$ No Practical \\
Proficiency \\
\end{tabular} & \begin{tabular}{|l|}
$\mathbf{0 +}$ \\
Memorized \\
phrases
\end{tabular} & $\begin{array}{l}\text { A2+Waystage+ } \\
\text { A2 Waystage } \\
\text { A1 Breakthroug } \\
\end{array}$ \\
\hline
\end{tabular}


Based on the results of an analysis of border guard officers' language level needs and a review of international standards for similar professions, the recommended minimum language proficiency target levels for each population were defined (Table 2).

Table 2 English Proficiency Requirements by SBGS population

\begin{tabular}{|l|c|c|c|}
\hline Population & Listening Level & Speaking Level & Reading Level \\
\hline SBGS instructors & 2 & 2 & 2 \\
\hline $\begin{array}{l}\text { SBGS officers serving } \\
\text { at the borders }\end{array}$ & 2 & $1+$ & $1+$ \\
\hline
\end{tabular}

In order to participate in international training and seminars, it was determined that SBGS officers-instructors should have a minimum of Level 2 in the three skill areas of listening, speaking, and reading. Writing in English is rarely used by this population, so should not be a required skill.

SBGS officers serving at the borders should have a minimum of Level 2 for interactive listening and a $1+$ in speaking and reading. These officers frequently come in contact with foreigners and need to understand a variety of speech responses and make important decisions based on those responses. Therefore, a Level 2 for listening comprehension is necessary. A slightly lower level of $1+$ for speaking and reading was diagnosed to be sufficient for this population. The speaking and reading target levels could be raised to a 2 if it were later discovered that the standards were too low.

Table 3 shows an estimate of the number of hours of classroom instruction an average student would need to progress from one level to the next. These estimates are of vital importance for the SBGSU in determining the number of training hours to allocate for each course. It also serves as a guideline for both teacher and learners to set expectations for student progress. Thus, the length of the courses was established at a 3-month program, which could allot 270 hours of direct classroom instruction (self-study hours were not included in this figure). Therefore, a student entering the course at a Level $0+$ should be able to attain a Level 1 by the end of the course. Some officers will be able to move up a whole proficiency level (from a $0+$ to a $1+$ or a 1 to a 2 ) after 3 months of intensive training, but many will not. Language learning is individual and uneven with many factors at play such as learners' age, natural language learning aptitude, motivation, and amount of English exposure.

Table 3 Estimate of Progress in Hours of Instruction ( 1 hour $=60$ minutes $)$

\begin{tabular}{|c|l|l|l|l|}
\hline $\begin{array}{c}\text { Target level / } \\
\text { Entry Level }\end{array}$ & \multicolumn{1}{|c|}{$0+$} & \multicolumn{1}{c|}{1} & \multicolumn{1}{c|}{$1+$} & 2 \\
\hline 0 & 200 hours & 400 hours & 600 hours & $800+$ hours \\
\hline $0+$ & $*$ & 200 hours & 400 hours & $600+$ hours \\
\hline 1 & $*$ & $*$ & 200 hours & $400+$ hours \\
\hline $1+$ & $*$ & $*$ & $*$ & $200+$ hours \\
\hline
\end{tabular}

\subsection{Program Goals}

The intensive 3-month English program is intended to provide border guard officers with extensive communicative practice in real-life situations. The course, comprised of two levels, will aim to equip the officers with the knowledge and skills needed to become 
successful English users who can maintain simple communication for routine social and work requirements.

The general program goals are:

- to develop general and professionally-oriented communicative language competencies in English to allow them to communicate effectively and confidently while performing service duties;

- to demonstrate English proficiency in socially and culturally appropriate ways when interacting with international visitors and foreign counterparts;

- to develop the skills for independent learning that will be used in the classroom and in future professional situations;

- to possess solid knowledge of professional border guard terminology and be able to use it in oral speech;

As have already been mentioned, the course was developed for two groups (Level 1 and Level 2).

Level 1: This is a beginner English course for officers who attained a Level 0+ on the English Language Proficiency Test. This course is designed to help students develop communication skills and strategies, increase general and professional English vocabulary, and build confidence using English through intensive practice and interesting professional tasks. All class activities and homework are intended to prepare officers to be successful users of English in real-world contexts. By the end of the course, students should be tested at a 1 to $1+$ level.

Level 2: This is an elementary English course for officers who attained a Level 1 on the English Language Proficiency Test. This course is designed to help students develop communication skills and strategies, increase general and professional English vocabulary, and build confidence using English in real-life situations through intensive practice and interesting professional tasks. All class activities and homework are intended to prepare officers to be successful users of English in real-world contexts. By the end of the course, students should take a test at a $1+$ to 2 level.

General IELC characteristics are the following:

- 12 weeks in duration (excluding placement and exit exams);

- 4.5 hours of classroom instruction per day plus 2 hours of homework and individual self-paced study (270 hours of classroom instruction plus 120 hours of homework and self-paced study);

- General English and professional English (ESP);

- Integrated skills approach, with an emphasis on listening and speaking;

- Students take a mandatory placement test before starting the course and are placed into courses according to language ability;

- Students take a mandatory exit test to assess their language proficiency.

\subsection{Placement Testing and Assessment of Learning Outcomes}

The main purpose of assessment and evaluation is to improve student learning. In particular, it is used to measure the success of instruction, program effectiveness, and student progress. The results of assessment help instructors determine student strengths and weaknesses in relation to the curricular objectives and also serve to assist instructors in adapting the curriculum, instructional approaches, and classroom practices. 
Student progress and curricular objectives for the IELC for border guard officers are evaluated using standardized criteria for each language skill and band levels as defined in the course objectives. Assessment is performed in the following forms:

- proficiency test used for placement and exit purposes;

- weekly achievement tests or quizzes;

- on-going informal classroom assessment and feedback.

A criterion-referenced, global assessment of functional listening, speaking, and reading proficiency was developed by the curriculum development team. A writing proficiency test is administered as it was determined in the needs analysis that little writing is needed by this specific border guard population. This test focuses on what the learner can "do" with the language rather than what he "knows." It tests global competence and contains an unlimited amount of material. It should not be confused with an achievement test which focuses on how much material from a specific course a learner has mastered.

The SBGSU Language Proficiency Test is comprised of two parts: an oral proficiency interview and a reading proficiency test. The oral interview is an interactive, adaptive, learner-centered assessment and is based on the ILR Language Proficiency Descriptions. The oral interview consists of several real-world tasks and can last from ten to twenty minutes, depending on the language ability of the candidate. It assesses interactive listening comprehension and speaking proficiency and is conducted by two raters. Each rater assigns the test candidate a score independently. If there is a discrepancy in the two raters' scores, evidence from the language sample is then re-examined until a final score can be assigned.

The reading proficiency test is a bi-level test comprised of ILR Language Proficiency Levels 1 and 2. Several reading texts with multiple-choice questions for each level are given to determine if the candidate understands the topic, main idea, and specific details as defined at each level. The following text types are used: newspaper and magazine articles; personal and professional correspondence; advertisements, guides, brochures and leaflets; public notices and signs; and timetables, programmes, agendas, and tickets. At Levels 1 and 2, texts are defined as concrete and contain high frequency vocabulary.

The English Language Proficiency Test is used only for placement and exit purposes for the 3-month intensive English course. When used as a placement test, test scores are used to determine which course would be most appropriate for the candidate based on his/her language proficiency level. When used as an exit test, scores are used to determine if a candidate has a sufficient English level to participate in professional work activities such as international training and other border guard duties.

English instructors develop and administer their own classroom achievement tests and quizzes. These assessments are used to determine what students have learned by measuring their mastery of specific vocabulary, structures, and content as taught in the course. While there is no standard format, it is important that if students are being trained in English, they are not assessed using their native language.

In addition to formal tests and quizzes, instructors give students regular informal, individual feedback as a means to monitor student progress and give students a wellrounded picture of their skills, abilities, and on-going progress. 


\section{Practical LeVEl of the UkRainian Border Guards' Foreign LANGUage COMPETENCE DEVELOPMENT}

\subsection{Administration}

For any course to succeed, the administration must work in partnership with the teachers to ensure that each student has the best possible educational experience. Both parties should ensure that the curriculum is properly developed, implemented, and monitored. They must also remain flexible to meet the changing needs of the students and adjust the English language curriculum to fit those needs.

One of the main responsibilities of the administration is in the selection of students for the courses, taking care to provide them with a solid rationale as to the goals, objectives, and purposes for the English language training. Because language learning is a difficult task, officers are released from their service duties for the duration of the course to concentrate solely on their English language studies. Professional growth and development should not stop at the end of the course. The students need to be supported and encouraged to continue their progress through professional development activities and further training.

\subsection{Students}

Learning a language is a difficult task and requires hard work and determination. It is especially challenging to learn in the limited time period of 3 months. In order to succeed, students should make an effort to attend all lessons and be active participants in classroom activities. This includes using only English with classmates and the instructor during class time and being tolerant and supportive of others in their attempts to reach their educational goals. In addition to in-class participation, students have to be diligent in preparing their home assignments and take additional opportunities to use English outside the classroom in order to develop their proficiency.

\subsection{English language instructors}

Instructors play a crucial role in the language development of their students. Not only do they serve as a model for the use of the English language, but they also encourage and motivate students in their language acquisition efforts. It is important, especially with beginners and less-confident learners, to create a positive, supportive atmosphere that promotes risk-taking. By providing students with opportunities for meaningful communication and focusing on the message rather than the mistake, the teacher will help build the confidence students need to become independent users of English. This will require an intent on the instructors' part to allow learners more equal opportunities for interaction in the classroom. This will involve giving learners more opportunities to interact with each other in English and not just practice grammatical forms. In addition, instructors will provide students with language that is at, or just above, the students' current level of understanding (comprehensible input), taking care not to overwhelm the student with language which is unrealistically beyond the scope of their understanding.

Using the curriculum as a guide, instructors will set achievable educational goals for students and carefully organize all class activities to meet those objectives. They will use a variety of assessment techniques to provide students with continuous feedback on their progress. During classroom teaching, instructors must be flexible and creative, using varied techniques taking into consideration the needs and personalities of each student. 
In addition to meeting the required minimum educational standards for teachers as set by the Ukrainian Ministry of Education, the language teacher should be proficient in oral and written English and demonstrate teaching competency. In particular, instructors for this course should have a solid background in the communicative language teaching approach and the basic terminology, situations and tasks needed by border guards.

\section{METHODOLOGICAL LeVEl OF THE UKRAINIAN BORDER GUARDS' FoREIGN LANGUAGE COMPETENCE DEVELOPMENT}

\subsection{Teaching approach and rationale}

The teaching approach used for the IELC is a communicative, interactive one, focusing on meaning as the starting point for language development, with grammatical form developing from meaning. Students are encouraged to use the language as much as possible to interact with the instructor and other students, even at the lowest levels. Because students are learning English in a foreign language context and have few opportunities to practice outside of class, they need as much exposure to English in class as possible. Therefore, the course methodology minimizes the use of the first language and translation in order to maximize the amount of exposure and opportunities for English practice.

The course topics and activities focus directly on the vocabulary students need for their professional careers and the kind of language activities they will need to engage in as determined in the needs analysis. Instructors give learners guidance in helping them develop their grammar, but grammatical accuracy is subordinate to fluency. Instructors encourage learners to use language freely during class activities and tasks, without worrying too much about accuracy. Semantics, function/notions, and grammatical structure practice are also explicitly taught, but following communicative activities.

\subsection{Learning methods}

The learning methods used are tailored to the needs of the course and therefore are basically communicative. According to the obtained results of the questioning conducted after the pilot courses there was compiled a list of activities that, in the opinion of students who completed the course, are most useful for the development of their language skills, they are presented in the order of frequency they were mentioned:

1. Pair-work and conversation practice,

2. Professional topics and terminology,

3. Daily communication,

4. Group discussion,

5. Listening exercises,

6. Role playing,

7. Translation,

8. Independent work,

9. Grammar practice,

10. Dialogs dramatization,

11. Learning vocabulary, 


\author{
12. Reading. \\ 13. Writing messages and larger written structures, \\ 14. Immersion in the linguistic environment/use of English only, \\ 15. Language laboratory \\ 16. Making presentations.
}

\title{
6. CONCLUSION
}

The analysis of the experience of development and conducting of IELC gives us reasons to assert that they are conducted at a high scientific and methodological level. The main attention is paid to developing the skills of listening and speaking (basic skills of oral communication). These are the very skills that border guards need most and the ones that they themselves want to have. It is precisely those skills that the officers have the least developed according to the results of testing their pre course level of language proficiency. The methodology of this course is aimed at forming border guards' foreignlanguage professional competencies, which will facilitate their effective service in the state border protection units. The course program provides border guards with the opportunity to develop the language competence and strategies they need to effectively engage in situations of professional communication that they can meet at the border, both while conducting border surveillance activities and border checks at the BCPs.

The problem of the border guards' foreign language competence improvement was considered on 3 levels.

Theoretical level included conducting of the needs analysis, defining language proficiency levels, setting the course goals, organizing entry and exit testing. The needs analysis helped to determine: the situations in which Ukrainian border guards will use the English language; the objectives and purposes for which English is needed; the types of communication that will be used; the level of proficiency that will be required.

The IELC Curriculum takes into account language proficiency levels as specified in the ILR Proficiency Levels, which are comparable with NATO STANAG 6001 levels. It was determined that SBGS officers-instructors should have at minimum a Level 2 in the three skill areas of listening, speaking, and reading. Writing in English is rarely used by this population, so should not be a required skill. SBGS officers serving at the borders should have at minimum a Level 2 for interactive listening and a $1+$ in speaking and reading. The length of the courses was established at a 3-month program, which could allot 270 hours of direct classroom instruction.

Assessment is performed in the forms of: proficiency test used for placement and exit purposes; weekly achievement tests or quizzes; on-going informal classroom assessment and feedback.

Practical level of the border guards' foreign language competence development provided for defining the roles and responsibility of the administration, students, teachers.

The administration must work in partnership with the teachers to ensure that each student has the best possible educational experience. Both parties should ensure that the curriculum is properly developed, implemented, and monitored. They must also remain flexible to meet the changing needs of the students and adjust the English language curriculum to fit those needs. The students should make an effort to attend all lessons and be active participants in classroom activities. This includes using only English with 
classmates and the instructor during class time and being tolerant and supportive of others in their attempts to reach their educational goals. Instructors serve as a model for the use of the English language, but they also encourage and motivate students in their language acquisition efforts. It is important, especially with beginners and less-confident learners, to create a positive, supportive atmosphere that promotes risk-taking.

Methodological level of the border guards' foreign language competence development encompasses teaching methodology and learning methods. The teaching approach used for the courses is a communicative, interactive one, focusing on meaning as the starting point for language development, with grammatical form developing from meaning. The learning methods used are tailored to the needs of the course and therefore are basically communicative. According to the obtained results of the questioning conducted after the pilot courses there was compiled a list of activities that, in the opinion of students who completed the course, are most useful for the development of their language skills

Prospects for further scientific research include elaborating recommendations for the effective students' selection procedure and conducting entrance examinations for participation in IELC for the personnel of various categories of the SBGS; developing proposals for improving the intensive ESP courses methodology based on the best practices of EU countries.

\section{REFERENCES}

Babich, O. "A model for the formation of a communicative and discursive culture of future officers-border guards." Scientific herald of the National University of Bioresources and Nature Management of Ukraine. Series: Pedagogy. Psychology. Philosophy. Kyiv: Millennium, 2017. Pp. 13-21.

Balendr, A. "Designing professionally oriented training courses for border guards in accordance with the sectoral qualifications framework based on the virtual aula platform."Information Technologies and Learning Tools, no. 63 (1) - 2018. Pp. 68-80.

Bidyuk, N. "Key vocational and pedagogical competences of andragogues in the USA." Adult education: theory, experience, perspectives. - 2011. - Issue. 3 (1). - Pp. 223230. Accessed: http://nbuv.gov.ua/UJRN/OD_2011_3(1)_30.

Bloshchynsyi, I. "Enhancement of cadets' practical training at the National Academy of the State Border Guard Service of Ukraine named after Bohdan Khmelnytskyi." Science and Education, Issue 4, Pp. 5-10 (2017).

Didenko, O. (2009). "Theory and methods of formation of professional creativity of future officers of the State Border Service of Ukraine." Accessed: March 26, 2018 from http://dspace.ltsu.org/bitstream/123456789/3002/2/Didenko.pdf

Krystopchuk, T. "Trends in the development of pedagogical education in the countries of the European Union." The dissertation of Dr. Ped. Sciences: 13.00.04, Kyiv. Boris Grinchenko University. - Kyiv, 2014. p. 559.

Ryndenko, N. "Tendencies of communicative training of cadets of the educational institutions of Border Guard Service of Republic Poland." Ph.D. thesis Khmelnytskyi, 2016. p. 226.

Zaskaleta, S. "Trends of professional training of spesialists of agrarian industry in the European Union countries." Monography / S. Zaskaleta; edited by S. Sysoeva; Mykolaiv National Agrarian University. - Mykolaiv: Ilion, 2013. p. 500. 